\title{
Clinical Characteristics, Comorbidities, Length of Stay, and Mortality of COVID-19 Patients in RSUD Cideres, Majalengka, West Java
}

\author{
Herry Garna, ${ }^{1}$ Dika Rifky Fernanda, ${ }^{2}$ Gibran Bramasta Dirgavansya, ${ }^{2}$ Heru Haerudin, ${ }^{3}$ \\ Zulmansyah Zulmansyah, ${ }^{1}$ Samsudin Surialaga, ${ }^{4}$ Lelly Yuniarti ${ }^{4}$ \\ ${ }^{1}$ Department of Child Health, Faculty of Medicine, Universitas Islam Bandung, Bandung, Indonesia, \\ ${ }^{2}$ Medical Undergraduate Study Program, Faculty of Medicine, Universitas Islam Bandung, Bandung, Indonesia, \\ ${ }^{3}$ RSUD Cideres, Majalengka, Indonesia, ${ }^{4}$ Department of Biochemistry, Nutrition and Biomolecular, \\ Faculty of Medicine, Universitas Islam Bandung, Bandung, Indonesia
}

\begin{abstract}
Until now, the world is still facing the COVID-19 pandemic caused by SARS-CoV-2. The number of deaths of COVID-19 patients in Indonesia is quite large when compared to other countries. Clinical manifestations, comorbidities, length of stay, and the mortality of COVID-19 vary widely in each study. This study analyzes clinical characteristics, comorbidities, length of stay, and mortality of COVID-19 patients in RSUD Cideres, Majalengka, West Java. This study is an observational study with total sampling and purposive sampling. Subjects were patients with nasal swabs confirmed SARS-CoV-2 and hospitalized at RSUD Cideres from January to July 2021. Clinical manifestations, comorbidities, length of stay, and mortality of COVID-19 patients aged $\geq 17$ years old, were extracted from medical records. Results showed that the majority of 213 COVID-19 patients were age 41-60 years 114 (53.5\%), female 114 (53.5\%), with an upper respiratory tract in 207 (97.1\%), and shortness of breath in $203(95.3 \%)$ patients. $153(71.8 \%)$ patients had a fever, while headache, diarrhea, and anosmia respectively $49(23.0 \%), 19(8.9 \%)$, and 10 (4.6\%), respectively. Vital signs were the Glasgow Coma Scale (GCS) normal in 190 (89.2\%) patients. Most of patients had respiration rate $>20 / \mathrm{min}$ in $201(94.3 \%)$, oxygen saturation $<90 \%$ in $98(46.0 \%)$, and chest x-rays: bronchopneumonia 134 (62.9\%) and pneumonia 23 (10.7\%). Comorbidities were hypertension, diabetes mellitus, and chronic heart failure in $74(34.7 \%), 56(26.2 \%)$, and 46 (11.7\%) patients, respectively. The length of stay who died for 1-7 days (22 patients) and 8-14 days (9 patients); means almost all patients (29 of 32) died during the length of stay for 1-14 days. In conclusion, the majority of COVID-19 patients at RSUD Cideres are female, aged 41-60 years, had upper respiratory tract/shortness of breath, GCS normal, saturation oxygen <90\%, chest x-rays: bronchopneumonia and pneumonia, comorbidities: hypertension, and length of stay for patients who died 1-7 days.
\end{abstract}

Keywords: Comorbidities, COVID-19, length of stay, mortality

\section{Karakteristik Klinis, Komorbitas, Lama Rawat, dan Mortalitas Pasien COVID-19 di RSUD Cideres, Majalengka, Jawa Barat}

\begin{abstract}
Abstrak
Hingga saat ini, dunia masih menghadapi pandemi COVID-19 yang disebabkan oleh SARS-CoV-2. Jumlah kematian pasien COVID-19 di Indonesia cukup besar jika dibanding dengan negara lain. Manifestasi klinis, komorbid, lama rawat, dan mortalitas pasien COVID-19 sangat bervariasi pada setiap penelitian. Tujuan penelitian ini menganalisis karakteristik klinis, komorbiditas, lama rawat, dan mortalitas pasien COVID-19 di RSUD Cideres, Majalengka, Jawa Barat. Penelitian ini adalah penelitian observasional dengan total sampling dan purposive sampling. Subjek adalah pasien dengan nasal swab terkonfirmasi SARS-CoV-2 dan dirawat di RSUD Cideres periode Januari hingga Juli 2021. Data manifestasi klinis, komorbid, lama rawat, dan mortalitas pasien COVID-19 usia $\geq 17$ diambil dari rekam medik. Hasil menunjukkan bahwa mayoritas 213 pasien COVID-19 berusia 41-60 tahun 114 (53,5\%) dan wanita 114 (53,5\%) dengan keluhan saluran napas atas 207 (97,1\%) dan napas pendek 203 (95,3\%) pasien. 153 (71,8\%) pasien mengalami demam, sedangkan sakit kepala, diare, dan anosmia masing-masing 49 (23,0\%), 19 $(8,9 \%)$, dan 10 (4,6\%) pasien. Tanda vital Glasgow Coma Scale (GCS) normal pada 190 (89,2\%) pasien. Kebanyakan pasien mempunyai frekuensi napas >20/menit pada $201(94,3 \%)$ pasien, saturasi oksigen $<90 \%$ pada $98(46,0 \%)$ pasien, serta rontgen toraks: bronkopneumonia pada 134 (62,9\%) pasien dan pneumonia pada $23(10,7 \%)$ pasien. Komorbid adalah hipertensi, diabetes melitus, dan chronic heart failure pada $74(34,7 \%), 56$ (26,2\%), dan 46 $(11,7 \%)$ pasien berturut-turut. Lama rawat pasien yang meninggal 1-7 hari (22 pasien) dan 8-14 hari (9 pasien), berarti hampir semua pasien (29 dari 32) meninggal selama rawat 1-14 hari. Simpulan, mayoritas pasien COVID-19 di RSUD Cideres adalah wanita, berusia 41-6o tahun, keluhan saluran napas atas/napas pendek, GCS normal, rontgen toraks: bronkopneumonia dan pneumonia, komorbid: hipertensi, serta lama rawat pasien yang meninggal paling banyak 1-7 hari.
\end{abstract}

Kata kunci: COVID-19, komorbid, lama rawat, mortalitas

Received: 4 October 2021; Revised: 18 December 2021; Accepted: 28 December 2021; Published: 31 December 2021

Correspondence: Dr. Lelly Yuniarti, S.Si., M.Kes. Department Biochemistry, Nutrition and Biomolecular, Faculty of Medicine,

Universitas Islam Bandung. Jln. Tamansari No. 22, Bandung 40116, West Java, Indonesia. E-mail: lelly.yuniarti@gmail.com 


\section{Introduction}

In late December 2019, a novel beta coronavirus (severe acute respiratory syndrome coronavirus 2 or SARS-CoV-2) first appeared in Wuhan, Hubei province, China. World Health Organization named the disease caused by this virus was coronavirus disease 2019 (COVID-19). This virus can be transmitted through droplets from infected people to spread quickly. On March 11, 2020, the World Health Organization declared a pandemic. ${ }^{1-4}$ According to the WHO data for February 2021, 110 million cases were found worldwide. Indonesia is ranked $18^{\text {th }}$ with a distribution of 175 thousand positive confirmed cases of COVID-19 in West Java province based on data from the Indonesian COVID-19 Task Force in June 2021.

Several risk factors can influence COVID-19 infection, such as older age, male, diabetes, hypertension, cardiovascular disease, and malignancy. ${ }^{5}$ Other studies also mention several risk factors, including older age, male, high body mass index, and smoking history. ${ }^{6}$ From the two studies, there were overlapping risk factors, namely old age, and male gender.

RSUD Cideres Majalengka is hospital in West Java area that hospitalized COVID-19 patients. Whether COVID-19 patients hospitalized at RSUP Cideres, Majalengka have different characteristics from COVID-19 patients in general? The purpose of this study was to describe clinical characteristics, comorbidities, length of stay, and mortality of COVID-19 patients in RSUD Cideres, Majalengka, West Java.

\section{Methods}

This research was an observational study with total sampling. Subjects were patients with nasal swabs confirmed SARS-CoV-2 and were hospitalized at RSUD Cideres, Majalengka from January to July 2021. The data was analyzed from secondary data (medical records) of clinical manifestations, comorbidities, length of stay, and mortality of COVID-19 patients aged $\geq 17$ years old. The data were tabulated and then processed using Graphpad Prism version 9.2.0.

The clinical characteristics analyzed were gender, age, vital signs, clinical signs and symptoms, accompanied by results of chest x-ray examination, comorbidities, length of stay, and mortality. The research was obtained from the Health Research Ethics Committee of the Universitas Islam Bandung ethical approval Number: 111/KEPK-Unisba/VIII/2021.

\section{Results}

The results of analysis of gender, age, vital signs, clinical signs and symptoms, results of chest x-ray examination, and comorbidities of COVID-19 patients can be seen in Table 1, while the length of stay and mortality of COVID-19 patients are in Table 2.

The majority of COVID-19 patients in RSUD Cideres, Majalengka were aged 41-60 years (53.5\%), female 114 (53.5\%), with complaints of upper respiratory tract 207 (97.1\%) and shortness of breath 203 (95.3\%). Fever only in 153 (71.8\%) patients, while headache, diarrhea, and anosmia were 49 (23.0\%), 19 (8.9\%), and 10 (4.6\%), respectively. Vital signs were the Glasgow Coma Scale normal in 190 (89.2\%) patients. Most of patients had respiration rate $>20 /$ minute in 201 (94.3\%) patients and oxygen saturation $<90 \%$ in 98 (46.0\%) patients.

The majority of COVID-19 patients on chest x-ray examination had bronchopneumonia and pneumonia in 134 (62.9\%) and 23 (10.7\%) patients. Comorbidities of patients found in the form of hypertension, diabetes mellitus, and chronic heart failure in 74 (34.7\%), 56 (26.2\%), and 46 (11.7\%) patients, respectively.

The length of hospital stay for COVID-19 patients who died was 1-7 days (22 patients) and 8-14 days (9 patients), respectively. It means almost all patients (29 of 32) died during the length of stay in the hospital for 1-14 days. The contingency test with fisher extract test shows that there is a relationship between the length of stay and mortality $(\mathrm{p}=<0.0001)$.

\section{Discussion}

Most of the COVID-19 patients hospitalized at the hospital RSUD Cideres, Majalengka were women aged $41-60$ years (53.5\%). It is different from the research in Jakarta by Surendra et al. 7 from March-July 2020 of 4,265 COVID-19 patients, although the same occurred over 40 years, but was more in men ( $52 \%$ vs. $48 \%$ ). This difference in results occurs because positive cases of COVID-19 in West Java are more common in women than men. Karyono and Wicaksana's ${ }^{8}$ study also in Indonesia based on data of the 


\section{Table 1 Clinical Characteristics and Comorbidities of COVID-19 Patients in RSUD Cideres Majalengka}

\begin{tabular}{|c|c|c|}
\hline Characteristics & $\mathbf{n}=\mathbf{2 1 3}$ & $\%$ \\
\hline \multicolumn{3}{|l|}{ Age (years) } \\
\hline $17-40$ & 41 & 19.3 \\
\hline $41-60$ & 114 & 53.5 \\
\hline$>61$ & 58 & 27.2 \\
\hline \multicolumn{3}{|l|}{ Gender } \\
\hline Female & 114 & 53.5 \\
\hline Male & 99 & 46.5 \\
\hline \multicolumn{3}{|l|}{ Signs/symptoms } \\
\hline Fever on admission & 153 & 71.8 \\
\hline $\begin{array}{l}\text { Complaint of upper } \\
\text { respiratory tract }\end{array}$ & 207 & 97.1 \\
\hline Shortness of breath & 203 & $95 \cdot 3$ \\
\hline Headache & 49 & 23.0 \\
\hline Diarrhea & 19 & 8.9 \\
\hline Anosmia & 10 & 4.6 \\
\hline Bowel obstruction & 9 & 4.2 \\
\hline Chest pain & 6 & 2.8 \\
\hline Urination disorders & 1 & 0.4 \\
\hline \multicolumn{3}{|l|}{ Vital signs } \\
\hline \multicolumn{3}{|l|}{ Glasgow Coma Scale } \\
\hline $7-9$ & 4 & 1.8 \\
\hline $10-14$ & 19 & 8.9 \\
\hline 15 & 190 & 89.2 \\
\hline Hypertension & 105 & 49.2 \\
\hline \multicolumn{3}{|l|}{ Pulse } \\
\hline$\leq 60$ & 3 & 1.4 \\
\hline $61-100$ & 119 & 55.8 \\
\hline$>100$ & 91 & 42.7 \\
\hline \multicolumn{3}{|l|}{ Respiration rate/min } \\
\hline$\leq 12$ & $\mathrm{O}$ & $\mathrm{O}$ \\
\hline $13-20$ & 12 & 5.6 \\
\hline$>20$ & 301 & 94.3 \\
\hline \multicolumn{3}{|l|}{ Oxygen saturation } \\
\hline$<90$ & 98 & 46.0 \\
\hline $91-95$ & 69 & 32.3 \\
\hline$\geq 96$ & 46 & 21.5 \\
\hline \multicolumn{3}{|l|}{ Chest x-rays } \\
\hline Bronchopneumonia & 134 & 62.9 \\
\hline Pneumonia & 23 & 10.7 \\
\hline Normal & 29 & 13.6 \\
\hline TB pulmonary & 13 & 6.1 \\
\hline Others & 14 & 6.5 \\
\hline \multicolumn{3}{|l|}{ Comorbidities } \\
\hline Negative & 66 & 30.9 \\
\hline Hypertension & 74 & 34.7 \\
\hline Diabetes mellitus & 56 & 26.2 \\
\hline Chronic renal failure & 46 & 11.7 \\
\hline
\end{tabular}

official website Indonesian COVID-19 Task Force, Ministry of Health Indonesia up to $3^{\text {rd }}$ June
2020 reported 28,233 the confirmed COVID-19 most at the age 31-45 years (29.3\%) and 4659 (27.3\%) years. Retrospective cohort study in Wuhan, China, based on the data from two hospitals in December 2019 and January 2020, the majority occurred in men (62\%) compared to women (38\%). ${ }^{9}$ Guan et al.' ${ }^{10}$ research from 552 hospitals and 30 provinces in China also reported that most COVID-19 occurred in men $(58.1 \%$ vs. $41.9 \%$ ). The meta-analysis was based on 42 studies, including many descriptions from China and the United States. Studies conducted in Italy, India, the United Kingdom, Singapore, and South Korea have a higher prevalence of males with COVID-19 than females. ${ }^{11}$

Clinical manifestations of COVID-19 vary widely in each study. The results of the COVID-19 study in Cideres, Majalengka, the most common clinical manifestation was upper respiratory tract complaints (97.1\%) and shortest of breath (95.3\%). Surendra et al.7 got the most common complaints in the form of cough (66\%), fever (53\%), malaise (35\%), and shortness of breath (32\%). Other clinical manifestations were headache, sore throat, runny nose, nausea/ vomiting, myalgia, chills, diarrhea, and abdominal pain. Karyono and Wicaksana ${ }^{8}$ got the most frequent manifestations were cough $(76.2 \%)$, history of fever $(50.4 \%)$, current fever (47.1\%), and shortness of breaths (41.6\%). Guan et al.' $\mathrm{s}^{10}$ research in China stated the majority was cough (67.8\%), fatigue (38.1\%), and sputum production (33.7\%). Systemic review and meta-analysis by Yang et al., ${ }^{12}$ including 46,248 patients, the most prevalent clinical symptom was fever, followed by cough, fatigue, and dyspnea. Also, Fu et al. ${ }^{1}$ stated that the most common clinical signs were fever, cough, and fatigue. Even though fever is the most common symptom in some studies, only $38-50 \%$ of COVID-19 patients show fever. ${ }^{10,13-15}$

Our study's main comorbidities were hypertension and diabetes mellitus (34.7\% and 26.2\%). Karyono and Wicaksana ${ }^{8}$ also stated that the most frequent comorbidities in Indonesia were hypertension (52.1\%), diabetes mellitus (33.6\%) in addition to cardiovascular disease (20.9\%), and obstructive pulmonary (15.1\%). Other comorbidities were respiratory problems (9.0), kidney disease (4.9\%), asthma (3.1\%), cancer (2.3\%), tuberculosis (1.8\%), liver disease (1.2\%), and diseases related to the immune system (1.2\%). Research in Jakarta by Surendra et al.,7 most comorbid on COVID-19 were hypertension 
Table 2 Length of Stay and Mortality of COVID-19 Patients in RSUD Cideres Majalengka

\begin{tabular}{lcccc}
\hline Length of Stay (Days) & $\begin{array}{c}\text { Death } \\
(\mathbf{n = 3 2 )}\end{array}$ & $\begin{array}{c}\text { Recovery } \\
(\mathbf{n = 1 8 1 )}\end{array}$ & $\begin{array}{c}\text { Percentage } \\
\mathbf{( \% )}\end{array}$ & p Value $^{*}$ \\
\hline $1-7$ & 22 & 10 & 5.5 & 0.0001 \\
$8-14$ & 9 & 116 & 64.1 & \\
$\geq 15$ & 1 & 55 & 31.4 & \\
\hline
\end{tabular}

Note: *Fisher's exact test, $\mathrm{p}<0.05$ significant

(19\%) and diabetes mellitus besides heart disease (10\%). Other comorbidities were COPD, chronic kidney disease, immunocompromised, liver disease, malignancy, and obesity. Prevalence of comorbidities in the COVID-19 infection patients includes hypertension, respiratory system disease, and cardiovascular disease. ${ }^{10}$ Most comorbidities appear to increase with males, and obesity is also associated with an increased risk of death. ${ }^{14}$

According to Keller et al., ${ }^{15}$ survivors of COVID-19 compared to living patients have more frequent sepsis and multi-organ disorders, including acute cardiac injury, ARDS requiring mechanical ventilation, and dialysis due to acute kidney injury. In addition, secondary infection and septic shock often occur in severe cases of COVID-19.

An x-ray examination of the lungs in our study showed bronchopneumonia (62.9\%) and pneumonia (10.7\%), meaning 3/4 COVID-19 patients on a chest $x$-ray were in the form of bronchopneumonia and pneumonia. Whether this is due to coronavirus or other causes requires further study. In this study, it is also apparent that in the 32 deceased COVID-19 patients, 29 (91\%) showed signs of bronchopneumonia and pneumonia, which worsened the disease. ${ }^{16-17}$ Hosseiny et al. stated that the radiological picture in COVID-19 is usually nonspecific, often overlapping with the concept of SARS and MERS. On chest x-ray examination, at least $85 \%$ showed abnormalities with $75 \%$ in both lungs. The pneumonic chest $\mathrm{x}$-ray compromise was predominantly bilateral (72.9\%). ${ }^{18}$

The length of hospitalization COVID-19 who safe in RSUD Cideres, Majalengka mostly 8-14 days $(64.1 \%)$ and $\geq 15$ days $(31.4 \%)$. Of the 32 COVID-19 patients who died, 22 patients were hospitalized for 1-7 days and nine for 8-14 days of hospitalization.

According to Wang et al., ${ }^{19}$ hospital stays of survival patients 26-29 days while COVID-19 patients died 3-8 days. The rapid progress of the disease was noted in the dead patients with a median survival time of 5 days after admission. Logistic regression analysis showed that fever, pneumonia, acute respiratory distress syndrome, diabetes mellitus, and cancer were the variables that showed independent and statistically significant associations with mortality. ${ }^{20}$ According to Zhang et al., ${ }^{21}$ respiratory failure remained the most frequent cause of death (69.5\%), followed by sepsis (28.0\%) and cardiac failure (14.6\%). Older patients with underlying comorbidities suffering COVID-19 were at risk of death. Rao et al. ${ }^{22}$ and Li et al. ${ }^{23}$ stated that the lower cycle threshold $(\mathrm{Ct})$ values may be associated with bad outcomes and that $\mathrm{Ct}$ values may help predict the clinical course and prognosis of COVID-19 patients. Still, Karahasan Yagci et al. ${ }^{24}$ stated that viral load was not a critical factor for hospitalization and mortality.

\section{Conclusions}

In conclusion, most COVID-19 patients at RSUD Cideres are female, aged 41-6o years, had upper respiratory tract/shortness of breath, normal GCS, oxygen saturation $<90 \%$. The chest $\mathrm{x}$-rays showed bronchopneumonia and pneumonia, and the comorbidities were hypertension. The length of stay for patients who died was 1-7 days.

\section{Conflict of Interest}

All authors state whether there was a conflict of interest in this article or not.

\section{Acknowledgements}

The researcher would like to thank the RSUD Cideres, Majalengka, and Unit of Research and Community Service (UPPM) Faculty of Medicine Universitas Islam Bandung, which supported 
the funding of this study (PDU grant contract Number: 034/UPPM/SPPP-DS/III/2021).

\section{References}

1. Fu L, Wang B, Yuan $\mathrm{T}$, Chen $\mathrm{X}$, Ao $\mathrm{Y}$, Fitzpatrick T, et al. Clinical characteristics of coronavirus disease 2019 (COVID-19) in China: a systematic review and metaanalysis. J Infect. 2020;80(6):656-65.

2. Long C, Xu H, Shen Q, Zhang X, Fan B, Wang $\mathrm{C}$, et al. Diagnosis of the coronavirus disease (COVID-19): rRT-PCR or CT? Eur J Radiol. 2020;126:108961.

3. Lamberghini F, Testai FD. COVID-2019 fundamentals. $J$ Am Dent Assoc. 2021;152(5):354-63.

4. Li X, Geng M, Peng Y, Meng L, Lu S. Molecular immune pathogenesis and diagnosis of COVID-19. J Pharm Anal. 2020;10(2):102-8.

5. Wang B, Zhong F, Zhang H, An W, Liao M, Cao Y. Risk factor analysis and nomogram construction for non-survivors among critical patients with COVID-19. Jpn J Infect Dis. 2020;73(6):452-8.

6. Setiati S, Harimurti K, Safitri ED, Ranakusuma RW, Saldi SRF, Azwar MK, et al. Risk factors and laboratory test results associated with severe illness and mortality in COVID-19 patients: a systematic review. Acta Med Indones. 2020;52(3):227-45.

7. Surendra H, Elyazar IRF, Djaafara BA, Ekawati LL, Saraswati K, Adrian V, et al. Clinical characteristics and mortality associated with COVID-19 in Jakarta, Indonesia: a hospital-based retrospective cohort study. Lancet Reg Health West Pac. 2021;9:100108.

8. Karyono DR, Wicaksana AL. Current prevalence, characteristics, and comorbidities of patients with COVID-19 in Indonesia. J Community Empowerment Health. 2020;3(2):77-84.

9. Zhou F, Yu TY, Du R, Fan G, Liu Y, Liu Z, et al. Clinical course and risk factors for mortality of adult inpatients with COVID-19 in Wuhan, China: a retrospective cohort study. Lancet. 2020;395(10229):1054-62.

10. Guan WJ, Ni ZY, Hu YU, Liang WH, Ou $\mathrm{CQ}, \mathrm{He}$ JX, et al. Clinical characteristics of coronavirus disease 2019 in China. N Engl J Med. 2020;382(18):1708-20.

11. Espinosa OA, Zanetti ADS, Antunes EF,
Longhi FG, Matos TAD, Battaglini PF. Prevalence of comorbidities in patients and mortality cases affected by SARS-CoV-2: a systematic review and meta-analysis. Rev Inst Med Trop Sao Paulo. 2020;62:e43.

12. Yang J, Zheng Y, Gou X, Pu K, Chen Z, Guo Q, et al. Prevalence of comorbidities and its effects in patients infected with SARS-CoV-2: a systematic review and meta-analysis. Int $J$ Infect Dis. 2020;94:91-5.

13. Bhatraju PK, Ghassemeh BJ, Nichols BJ, Kim $\mathrm{R}$, Jerome KR, Nalla AK, et al. COVID-19 in critically ill patients in the seattle region-case series. N Engl J Med. 2020;382(21):201222.

14. Inciardi RM, Adamo M, Lupi L, Cani DS, Di Pasquale M, Tomasoni MD, et al. Characteristic and outcomes of patients hospitalization for COVID-19 and cardiac disease in Northern Italy. Eur Heart J. 2020;41(19):1821-9.

15. Keller KG, Reangsing C, Schneider JK. Clinical presentation and outcomes of hospitalized adults with COVID-19: a systematic review. J Adv Nurs. 2020;76(12):3235-57.

16. Shao F, Xu S, Ma X, Xu Z, Lyu J, Ng M, et al. In-hospital cardiac arrest outcomes among patients with COVID-19 pneumonia in Wuhan, China. Resuscitation. 2020;151:1823.

17. Himmels JPW, Borge TC, Brurberg KG, Gravningen KM, Feruglio SL, Berild JD. COVID-19 and risk factors for hospital admission, severe disease and death - a rapid review, $3^{\text {rd }}$ update [Internet]. Oslo: Norwegian Institute of Public Health; 2020 [updated 2020 November 15; cited 2021 August 23]. Available from: https:// www.fhi.no/globalassets/dokumenterfiler/ rapporter/2020/covid-19-and-risk-factorsfor-hospital-admission-severe-disease-anddeath-3rd-update-memo-2020-v2.pdf.

18. Hosseseiny M, Kooraki S, Gholamrezanezhad A, Reddy S, Myers L. Radiology perspective of coronavirus disease 2019 (COVID-19): lessons from severe acute respiratory syndrome and Middle East respiratory syndrome. Am J Roentgenol. 2020;214(5):1078-82.

19. Wang L, He W, Yu X, Hu D, Bao M, Liu H, et al. Coronavirus disease 2019 in elderly patients: characteristics and prognostic factors based on 4-week follow up. J Infect. 2020;80(6):639-45. 
20. Rodriguez-Morales AJ, Cardona-Ospina JA, Gutiérrez-Ocampo E, Vilamizar-Peña R, Holguin-Rivera Y, Escalera-Antezana JP, et al. Clinical, laboratory and imaging features of COVID-19: a systematic review and meta-analysis. Travel Med Infect Dis. 2020;34:101623.

21. Zhang B, Zhou X, Qiu Y, Song Y, Feng F, Feng J, et al. Clinical characteristics of 82 cases of death from COVID-19. PLoS One. 2020;15(7):eo235458.

22. Rao SN, Manissero D, Steele VR, Pareja J. A narrative systematic review of the clinical utility of cycle threshold values in the context of COVID-19. Infect Dis Ther. 2020;9(3):573-86.

23. Li Y, Yang Z, AiT, Wu S, Xia L. Association of "initial CT" findings with mortality in older patients with coronavirus disease 2019. Eur Radiol. 2020;30(11):6186-93.

24. Karahasan Yagci A, Sarinoglu RC, Bilgin H, Yanılmaz Ö, Sayın E, Deniz G, et al. Relatioship of the cycle threshold values of SARS-CoV-2 polymerase chain reaction and total severity score of computerized tomography in patients with COVID-19. Int J Infect Dis. 2020;101:160-6. 